\title{
Accounting Education and Labor Market Needs
}

\author{
Mr. MESHARI ALHUSSAIN \\ Umm Al-Qura University, College of Business Administration \\ E-mail: mahussain@uqu.edu.sa
}

$\begin{array}{lcr}\text { Received: August 5, } 2019 & \text { Accepted: Sep 22, } 2019 \quad \text { Published: December 1, } 2019 \\ \text { doi:10.5296/ajfa.v11i2.15276 } & \text { URL: https://doi.org/10.5296/ajfa.v11i2.15276 }\end{array}$

\begin{abstract}
The study aimed at identifying the appropriateness of educational outputs in the Saudi public universities for the labor market from the point of view of graduates from the specialization of accounting and finance by investigating the following axes (Motivation in specialization identification, teaching staff in universities, the appropriateness of the study plan for the labor market, and the extent of knowledge of professional tests) and its impact on the quality of educational outputs. The study adopted the inductive method trough reviewing the previous studies regarding the research subject. On the field study, the study used the questionnaire as the study tool. On the statistical side, the following statistical analyzes were conducted (frequencies, percentages, arithmetic means and standard deviations), as well as Pearson correlation coefficients to determine the relationships between the variables of the study. The study population consisted of all graduates from the accounting and finance departments of the Saudi public universities working in the public sector or the private sector or self-employed " entrepreneurial". The field study was carried out in 2018 and the number of participants was (125) graduates from Saudi public universities and (80\%) of the participants were under the age of (30) years. This is an excellent percentage as the study focused more on graduates. The study concluded the approval of the sample on each of the following: (the specialization identification was their personal desire, the teaching staff at the university is characterized by knowledge and eruditeness, the quality of study plans in universities and their knowledge of the study plan and its requirements, quality of educational outputs). It also concluded that the most prominent obstacles for graduates in the professional tests was the high financial fees of professional tests. In addition to there was no relationship between the specialization identification and the quality of educational outputs, while there was a relationship between (the efficiency of the teaching staff, the study plan, and the professional tests) and the quality of the educational outputs.
\end{abstract}

Keywords: University Accounting Education, Educational Outputs. 


\section{Research's Introduction and Methodological Framework}

\subsection{Introduction}

The continuous evolution in all different fields requires us to keep up with these changes and seek towards the best. The financial and accounting field is one of the most important pillars in any sector, whether in the public or private sectors. Regarding the previous financial events, we have the best attestation of the importance of this field and the great impact caused by any weakness in the financial and accounting sector for examples at the international level what happened at Enron in the United States of America in 2001, as for the local level in Saudi Arabia, the best example is what happened to Mobily in 2014 as the company made a proof of income before gaining it among other violations and errors that led to share price collapse in the company as the share collapsed in September from 92SR to less than 45SR in December of the same year. The educational authorities at all different levels provides education, guidance, and training for students, but this has led to the arrival of students to the required level of skill to meet the requirements of the labor market and there is no doubt that this matter varies from one student to another and from one educational entity to another. The student has the responsibility to strive for developing and educating himself and to try to gain experience in the field he wishes. Universities have no responsibility for qualifying students for the labor market because universities are the center of studies, researches and experiments rather than a product line for the labor market. In addition, the requirements of the labor market vary from one company to another as industrial companies have their requirements in financial majors that differ from the requirements of a financial service company or financial management in a public sector or a brokerage company.

The Gulf countries, including Saudi Arabia, are witnessing economic growth and a steady increase in the size and number of public and private facilities. The interest in the development of technology, information systems, and modern management methods undoubtedly need a special type of cadres required by these facilities in terms of scientific and personal qualifications. Therefore, Gulf academic institutions should not be isolated from global trends in the development of accounting education (Boudy, 1998).

\subsection{Study Problem}

The study problem can be summarized in the following question:

Are the outputs of accounting education in Saudi public universities satisfying the needs of the Saudi labor market? By focusing on the following axes (specialization identification, teaching staff, study plan, professional tests, educational outputs).

\subsection{Study Objectives}

The study aimed at identifying the appropriateness level of educational outputs in the Saudi public universities for the labor market, from the point of view of graduates in the field of accounting and financing and employees in the public and private sector or in a personal work through investigating the following axes which are : (Motivation in specialization identification, 
teaching staff in universities, the appropriateness of the study plan for the labor market, and the extent of knowledge of professional tests) and their impact on educational outputs.

\subsection{Study Importance}

The changing world requires us to reconsider what accounting education means in order to prepare individuals for the period of digital imbalance, thus future accountants must be flexible and adaptable. In order to achieve this, their educational needs must be comprehensive, integrated, innovative and diverse (McGuigan; Ken, 2016). The university accounting education faces a lot of criticism due to the widening gap between the university accounting education and the desired qualification requirements for practicing accounting profession (Alwabel; Juma'ah, 1997, A).

Accounting services have become more extensive and specialized, and are no longer limited to the understanding, interpretation and application of accounting standards, but increased the need for innovation and development to confront the change in the demand for accounting services in a world characterized by international competition according to the report of the "Bedford Committee" established by The American Accounting Association in 1986 (Al-wabel; Juma'ah, 1997, A).

(Khalil, 2005) emphasized the existence of a real problem represented in the low efficiency and effectiveness of inputs, methods, and outputs of accounting education in Arab universities, in addition to the scarcity of accounting studies interested in assessing the reality and future of accounting education.

One of the main reasons for paying attention to the development of accounting education programs is the change in the role of the accountant within the facility. As, the traditional tasks performed by the accountant from bookkeeping and reporting are automatically implemented depending on the programming, which led to the assignment of accountants in roles with analytical and diagnostic aspects, as the accountant produces information based mainly on the outputs of financial information systems programmed on the computer (Boudy, 1998).

The study plans in the accounting programs in the Saudi universities are different, not only in the overall structure of the program, but also in the quantity and type of accounting knowledge provided to the student and this is what was referred to by the study of (Al-wabel; Juma'ah, 1997, B) which concluded that the difference in knowledge is accompanied by varying methods of teaching and the used means due to the following:

1. The diversity schools to which faculty members belong in Saudi universities.

2. The absence of a clear and specific teaching plan for each course in some universities and leaving the determination of the content of the course and the method of teaching to the professor of the subject.

3. Lack of familiarity of some faculty members with the necessary knowledge in the field of computers limiting their use of computers in the curriculum and the lack of computers in some universities. 


\section{Ml Macrothink}

Asian Journal of Finance \& Accounting

ISSN 1946-052X

2019, Vol. 11, No. 2

4. The diversity of courses taught by faculty member per class reducing the chance of creativity in teaching methods.

5. The old courses and references used in some universities in a way that does not meet the requirements of the modern qualification of the graduates of accounting compared to what is taught in other universities.

6. Lack of coordination between accounting departments in Saudi universities whether in the field of curriculum identification or in the development of methods and means of teaching.

(Al-Asmari, 2018) pointed out that the importance of university accounting education is reflected in its role in the economic development of countries, so the graduate of the accounting specialization must be qualified to help him perform his job in a positive and effective manner.

\subsection{Previous Studies}

(Al-wabel; Juma'ah, 1997, B)

The study aimed at analyzing and evaluating the status of accounting programs in Saudi universities and he proposed the framework of accounting education in the Kingdom of Saudi Arabia. In order to achieve this objective, the study presented the elements of the necessary vocational qualification for practicing the profession of accounting through the recommendations of scientific and professional councils and related studies. The study explained that an accountant in service must have a combination of general knowledge as well as accounting knowledge and business areas with the need of acquiring many skills in communication, information systems, decision making, leadership, and professional conduct. The study included a framework for the development of accounting education in Saudi universities. This strategic framework emphasized the need to clearly define the message of the accounting department clearly which is achieving excellence in finding, discovering, transferring and applying accounting knowledge and skills through achieving excellence in research and accounting education and contributing to excellence in accounting application.

(Khalil, 2005)

The study aimed at assessing the current situation in the inputs and outputs of accounting education. In order to achieve this, the researcher extrapolated and analyzed the related previous studies, and the design of both survey lists distributed to members of the faculty in Jordanian universities and the other list to students. The study conclude that there was a positive relationship between (teaching competencies, accounting curriculum, infrastructure of the teaching process) and the quality of education. It has also been shown that there was weakness in keeping pace with the competencies, curriculums, and infrastructure of knowledge developments.

(Boudy, 1998) 


\section{Macrothink}

The study aimed at highlighting the programs of academic education and training in accounting field with a focus on undergraduate programs and how to promote those programs. The study concluded that the accounting and training programs are witnessing developments aimed at increasing the effectiveness of these programs to prepare cadres capable of dealing with the work environment. One of the most important challenges facing accountants is to understand the role that accounting systems play in modern information systems, and to acquire the required personal, technical and analytical skills and abilities. Also, dealing with the modern technology and programs required by the accountant is essential.

(Hassan, 2018)

The study aimed at identifying the compatibility of accounting education with the requirements of the labor market from the point of view of accountants and employers in institutions and local Non-Governmental Associations (NGOs) in the Gaza Strip. The questionnaire was used to test the hypotheses of the study. The number of valid questionnaires for the analysis was (220) in addition to (15) interviews with officials of NGOs. The study concluded that the accounting education of knowledge, experience, skills, and courses is capable of meeting the requirements of the labor market. The "field" training has helped the graduates to enhance their expertise. Also, the accounting curriculum needs more communication with computer science to be heavily supported by the market in operations. The methods used in teaching need to be updated to better suit the scientific and professional requirements of the labor market. However, universities have helped graduates develop their administrative, supervisory, and decisionmaking skills.

\section{(Al-Zamili, N.D.)}

The study aimed at examining the subject of accounting education and showing its role in developing the professional skills of graduates of the accounting department, namely intellectual, technical, practical skills, personal skills, communication skills, organizational skills and business management through a survey of the views of faculty members and graduates of the accounting department at the University of Qadisiyah in Iraq. The study concluded that accounting education helps to develop technical and practical skills but other skills, namely, mastering information technology and risk taking couldn't be developed by accounting education according to the sample. In addition, the study concluded that accounting education helps to develop the personal skills of graduates of the accounting department, namely self-learning, self-management, organization of work, respect for time, selection and prioritization within limited resources, introduction of ethical values, and professional attitudes in decision making, while adaptive skills in the business environment, accounting education does not help to develop them.

\subsection{Study Hypotheses}

The study consisted of independent variables and a dependent variable. The independent variables consisted of the following axes (specialization identification, teaching staff, study plan, professional tests, educational outputs), while the dependent variable is (the quality of educational outputs). The independent variable and the dependent variable are defined, as (Al- 


\section{Macrothink}

Asian Journal of Finance \& Accounting

ISSN 1946-052X

2019, Vol. 11, No. 2

Assaf, 2012) stated that the independent variable is the used factor or reason to determine its effect on the outcome. While the dependent variable meant that: the result of which the effect of the independent variable is measured. (Murad, 2011) explains that the independent variables are the researcher's interest in studying their effect on other dependent variables as the independent variables are called experimental variables or processors. While the dependent variables are affected by an experimental or independent variable. Therefore, the hypotheses can be formulated as follow:

1. There is a relationship between specialization identification and the quality of educational outputs.

2. There is a relationship between the efficiency of teaching staff and the quality of educational outputs.

3. There is a relationship between the study plan and the quality of educational outputs.

4. There is a relationship between the professional tests and the quality of educational outputs.

\subsection{Study Community}

The study targeted graduate students from the Saudi universities in the field of accounting and finance, full-time students (Internal Student) and didn't target part-time students (External student). It also targeted all the following degrees (Bachelor, Master, PhD). The study also targeted working graduate students whether in the public or the private sector, or personal business and trade and it didn't target the unemployed. The study community can be summarized in the following points:

- Graduates from public universities in accounting and finance.

- Full-time learners (Internal Student)

- Working people.

\subsection{Study Methodology}

The study followed the inductive approach in the theoretical aspect by reviewing the previous studies related to the subject of the research. On the field side, the study used the questionnaire as a research tool. The five-point Likert scale was used, and the questionnaire is usually used as a research tool when the required information is the private respondent's view or personal opinion in a particular case (Al-Assaf, 2012). The questionnaire can be defined as "an appropriate tool for obtaining information, data, and facts related to a given reality." (Obeidat et al., 2007, 104). The study community consisted of all graduates from the accounting and financial departments of the Saudi public universities working in the public sector or the private sector or self-employed " entrepreneurial". 


\section{Mll Macrothink}

\section{Theoretical framework}

\subsection{Accounting education (its important, objectives, and elements)}

The universities seek in developing their educational programs to meet the needs of the labor market and also to work on the qualification of accounting outputs that have the compatible skills and experiences with the labor market. The association between education and professional practice is important for the progress of the accounting profession. Therefore, educational institutions will be required to meet the needs of the labor market with the highest efficiency and effectiveness (Hassan, 2018).

Accounting is defined as an art that relies on the use of the self-capacity of accountants to judge the economic and financial events facing accounting work (Qitnani, Aweys, N.D).

While accounting education can be defined as an organized process carried out by the responsible bodies including universities in the forefront and this process provides the learner with the basic knowledge and the necessary scientific and practical capabilities that enable him to practice the profession of accounting (Bouazaria; Londar, 2017). Due to the importance of training and experience in changing the behavior of accountants and developing their skills and professional competence through increasing knowledge and skills development and bridging the gap between the requirements of the labor market and the capabilities and abilities of accountants, which is advocated by most professional organizations in most countries of the world that the applicant who wants to obtain a legal accounting certificate must complete training requirements and experience (Saleh, 2017).

The importance of good and effective accounting education can be summarized as follows (Bouazaria; Londar, 2017):

1. Contribution to the preparation and rehabilitation of accounting frameworks through providing them with different accounting knowledge.

2. Providing accounting frames in various economic units with the most important developments that accompany the profession.

3. Assistance in meeting the requirements of economic development and meet the needs of the work environment.

4. Assistance in identifying the needs of economic units of programs and training courses and solving the problems faced by these units.

5. Good accounting education contributes to the development of the accounting profession through the development of programs according to modern developments.

In addition, (Saleh, 2017) emphasized that accounting education occupies a prominent importance compared to other specialization. This importance stems from the role played by the accounting profession in the development of accounting practices in society. 


\section{Mll Macrothink}

Asian Journal of Finance \& Accounting

ISSN 1946-052X

2019, Vol. 11, No. 2

The development of accounting education is of great interest because it contributes to the development of the accounting profession. In addition, the development of accounting education increases the efficiency of graduates of the accounting departments, enabling them to meet the demands of the labor market. This led the International Federation of Accountants to issue international standards on accounting education and contribute to the development of its outputs in line with the requirements of the accounting profession (Bouazaria; Londar, 2017).

(Al-Zamili, N.D.) emphasized that there are two approaches to accounting education, namely the traditional approach and the modern approach. The modern approach is the best because it has the ability to prepare accounting outputs that are able to take in the scientific and analytical models and enable them to be familiar with the requirements of practicing the profession.

University institutions play an important role in preparing qualified accounting competencies through what they should do to focus on acquiring the learner's abilities and professional skills, and moving from the traditional approach in education to the skills transfer approach. In other words, the skills developed during the different educational stages can benefit the person who gains it from entering the labor market (Saleh, 2017). However, although the primary objective of the academic institutions is to prepare students scientifically and practically, they can contribute to the training due to the availability of qualified competencies in these institutions. But institutions are not expected to expand into specialized training areas associated with specific types of work given the nature of these institutions (Boudy, 1998).

The importance of accounting education is clearly demonstrated by the continuing need for accounting work within any community, therefore, it is necessary to create accounting cadres with the necessary skills to carry out the required tasks in the correct and appropriate manner (Al-Zamili, N.D.). The goals of accounting education can be summarized in the following points (Bouazaria; Londar, 2017):

- Increasing the efficiency and effectiveness of the outputs of accounting education.

- Ensuring the optimal use of accounting education resources.

- Developing accounting curricula and developing the accounting profession.

- Providing cadres for the labor market.

- Focusing on accounting education is to be committed to the ethics and professional behaviors to which the profession must adhere.

However, the elements of accounting education are as follows (Qitnani, Aweys, N.D, 7):

1. Inputs: Persons who can be prepared to practice accounting work (in all its forms and types).

2. Operations: The means of education that can be used to provide accounting skills.

3. Outputs: Qualified persons who are capable of practicing accounting (academic or professional) to achieve the goal of the accounting education system in general. 


\section{MIMacrothink}

Asian Journal of Finance \& Accounting

ISSN 1946-052X

2019, Vol. 11, No. 2

4. Reverse feedback (Control): through monitoring, evaluating and developing the above elements and trying to correct any deviations that occur in any of them.

\subsection{Saudi Vision 2030}

The vision of the Kingdom of Saudi Arabia (2030) (Note 1) has included continuing investment in education and training, enhancing efforts to align the outputs of the educational system with the needs of the labor market through the launch of the National Employment Portal, establishing professional councils to identify the needs of each development sector, expanding vocational training, and increasing opportunities for scholarships on areas that serve the national economy, as well as focusing on innovation, advanced technologies and entrepreneurship. The vision has included seeking to develop education, guide students towards appropriate career options, and become at least five of the top (200) international universities by 2030 . This will be achieved through the development of advanced educational curricula focusing on personal skills, talent development, teacher qualification, monitoring the level of progress in this aspect, publishing the results of indicators that measure the level of education outputs annually, working with specialists to ensure that higher education outputs are aligned with labor market requirements, establishing partnerships with those who provide training opportunities for graduates locally and internationally, establishing human resource platforms in different sectors to enhance training and rehabilitation opportunities, enabling the private sector to invest in education, and eliminating all obstacles to the private sector's great role in development.

\section{Practical Framework}

\subsection{Sample Description: Personal characteristics of the study sample}

The sample included (125) graduates from Saudi public universities. The characteristics of the sample can be characterized as follows:

\section{Part 1: Demographic Characteristics:}

\section{Gender}

Table 1. Distribution of the sample according to gender

\begin{tabular}{|c|c|c|}
\hline Gender & Frequency & Percent \% \\
\hline Female & 77 & 61.6 \\
\hline Male & 48 & 38.4 \\
\hline Total & 125 & 100.0 \\
\hline
\end{tabular}

Table 1 shows the distribution of the sample according to gender. The female sample was $(61.6 \%)$, while males $(38.4 \%)$ of the total sample.

2. Age 


\section{Macrothink}

Table 2. Distribution of the sample according to age

\begin{tabular}{|c|c|c|}
\hline Age & Frequency & Percent \% \\
\hline Less than 30 years & 99 & 79.2 \\
\hline From 30 to less than 40 & 20 & 16.0 \\
\hline From 40 to less than 50 & 5 & 4.0 \\
\hline 50 years and above & 1 & 0.8 \\
\hline Total & 125 & 100.0 \\
\hline
\end{tabular}

The sample of the study was distributed according to age as shown in Table (2). The vast majority of the sample was represented by the age group (less than 30 years) by $(79.2 \%)$, followed by the age group (from 30 to less than 40 years) by (16\%). The age group (from 40 to less than 50 years) was (4\%), until the lowest age group regarding age (50 years and above) was represented by one individual only by $(0.8 \%)$ of the sample. Thus, the majority of the sample was from the younger age groups and it is the best in the current situation of the current accounting education outputs.

\section{Graduation Date}

Table 3. Distribution of the sample according to graduation date

\begin{tabular}{|c|c|c|}
\hline Graduation Date & Frequency & Percent \% \\
\hline less than one year & 51 & 40.8 \\
\hline From one year to less than 3 years & 33 & 26.4 \\
\hline From 3 years to less than 5 years & 14 & 11.2 \\
\hline 5 years and above & 27 & 21.6 \\
\hline Total & 125 & 100.0 \\
\hline
\end{tabular}

The results indicated that the date of graduation of the sample of (less than one year) came in the first rank by (40.8\%) of the total frequencies, followed by the date of graduation (from one year to less than 3 years) by (26.4\%), followed by those who graduated from 5 years and above by $(21.6 \%)$, until the lowest rate of the graduation date group (from 3 years to less than 5 years) achieved (11.2\%) as shown in Table (3). Thus, the data indicated that the sample is represented by graduates, which is the best for the study, as they understand the best vision of the outputs of education in the current situation and their relationship is better with the practical reality in the field of work in the current period.

\section{Universities}


Table 4. Distribution of the sample according to universities

\begin{tabular}{|c|c|c|}
\hline University & Frequency & Percent \% \\
\hline Imam University & 24 & 19.2 \\
\hline King Saud University & 12 & 9.6 \\
\hline Umm Al-Qura University & 9 & 7.2 \\
\hline Princess Nourah University & 8 & 6.4 \\
\hline Taibah University & 7 & 5.6 \\
\hline King Abdulaziz University & 6 & 4.8 \\
\hline Majmaah University & 4 & 3.2 \\
\hline Najran university & 3 & 2.4 \\
\hline University of Ha'il & 3 & 2.4 \\
\hline University of Tabuk & 3 & 2.4 \\
\hline Qassim University & 3 & 2.4 \\
\hline Taif University & 3 & 2.4 \\
\hline Al-Baha university & 1 & 0.8 \\
\hline Didn't mention any university & 39 & 31.2 \\
\hline Total & 125 & 100.0 \\
\hline
\end{tabular}

A variety samples of Saudi universities participated in the study as shown in Table (4) as the highest universities participated in the study was from Imam University by (19.2\%), followed by King Saud University by ( $9.6 \%)$, and then Umm Al-Qura University by (7.2\%), followed by Princess Nourah University by $(6.4 \%)$, while the lowest universities represented in the sample was Al-Baha university represented by one unit, while $(31.2 \%)$ of the sample did not mention the university name. Thus, the sample distributed in a good manner on the large Saudi universities, which indicates the efficiency of measuring the outputs of education well and its relationship to reality and the requirements of the labor market.

\section{Scientific Degrees:}

Table 5. Distribution of the sample according to scientific degrees

\begin{tabular}{|c|c|c|}
\hline Scientific Degree & Frequency & Percent \% \\
\hline BA & 110 & 88.0 \\
\hline M.A. & 13 & 10.4 \\
\hline Ph.D. & 2 & 1.6 \\
\hline Total & 125 & 100.0 \\
\hline
\end{tabular}

The results showed that the sample was distributed according to the scientific degree, where the vast majority reached (88\%) of the sample for the category of education with a bachelor's degree, followed by the category of education obtained by the master sample by $(13 \%)$ of the sample, until the lowest percentage of the sample representation of $\mathrm{PhD}$ degree was $(1.6 \%)$ of the total sample. Therefore, the sample is considered a good representation of the degrees as shown in Table (5). 


\section{Employer}

Table 6. Distribution of the sample according to employer

\begin{tabular}{|c|c|c|}
\hline Scientific Degree & Frequency & Percent \% \\
\hline Public sector & 30 & 24.0 \\
\hline Private sector & 7 & 56.8 \\
\hline Personal work or business & 24 & 19.2 \\
\hline Total & 125 & 100.0 \\
\hline
\end{tabular}

The results showed that the sample was distributed according to the employer, where work in the private sector came in the highest percentage by $(56.8 \%)$, followed by the government sector by $(24 \%)$, until the lowest percentage of the sample of whom working in personal work or business came in (19.2\%) of the total sample as shown in Table (6). Thus, it is possible to say that the sample is represented by the three sectors of labor in proportion to the needs of the work as they have the best vision towards the outputs of education in the labor market.

\subsection{Validity and Reliability Tests:}

\section{- Validity of the tool:}

The validity test of the tool was carried out by calculating the internal validity of the questionnaire axes between each item and the axis to which it belongs. The results were as shown in the following table:

Table 7. The correlation coefficients between each item and the total score of the axis to which it belongs

\begin{tabular}{|c|c|c|c|c|c|}
\hline Item & $\begin{array}{c}\text { Correlation } \\
\text { Coefficient }\end{array}$ & Item & $\begin{array}{c}\text { Correlation } \\
\text { Coefficient }\end{array}$ & Item & $\begin{array}{c}\text { Correlation } \\
\text { Coefficient }\end{array}$ \\
\hline 1 & $0.55^{* *}$ & 12 & $0.49^{* *}$ & 23 & $0.46^{* *}$ \\
\hline 2 & $0.48^{* *}$ & 13 & $0.33^{* *}$ & 24 & $0.68^{* *}$ \\
\hline 3 & $0.67^{* *}$ & 14 & $0.59^{* *}$ & 25 & $0.64^{* *}$ \\
\hline 4 & $0.59^{* *}$ & 15 & $0.52^{* *}$ & 26 & $0.65^{* *}$ \\
\hline 5 & $0.68^{* *}$ & 16 & $0.46^{* *}$ & 27 & $0.68^{* *}$ \\
\hline 6 & $0.74^{* *}$ & 17 & $0.36^{* *}$ & 28 & $0.43^{* *}$ \\
\hline 7 & $0.80^{* *}$ & 18 & $0.55^{* *}$ & 29 & $0.79^{* *}$ \\
\hline 8 & $0.79^{* *}$ & 19 & $0.62^{* *}$ & 30 & $0.75^{* *}$ \\
\hline 9 & $0.73^{* *}$ & 20 & $0.48^{* *}$ & 31 & $0.79^{* *}$ \\
\hline 10 & $0.76^{* *}$ & 21 & $0.52^{* *}$ & 32 & $0.77^{* *}$ \\
\hline 11 & $0.68^{* *}$ & 22 & $0.30^{* *}$ & 33 & $0.55^{* *}$ \\
\hline
\end{tabular}

** Significant at 0.01

Table (7) showed the results of the validity test of the tool. All the correlation coefficients were positive and statistically significant at the mean of 0.01 , and ranged from ( 0.30 to 0.80$)$ indicating the validity of the items of these axes. 


\section{NI Macrothink}

Asian Journal of Finance \& Accounting ISSN 1946-052X 2019, Vol. 11, No. 2

Correlation was calculated between the axes and the total score of the questionnaire and the results were as follows:

Table 8. Correlation coefficients between the axes and the total score of the questionnaire

\begin{tabular}{|l|c|}
\hline \multicolumn{1}{|c|}{ Axis } & Correlation Coefficient \\
\hline The first axis: Specialization Identification & $0.60^{* *}$ \\
\hline The second axis: Teaching Staff & $0.72^{* *}$ \\
\hline The third axis: Study Plan & $0.66^{* *}$ \\
\hline The fourth axis: Professional Tests & $0.63^{* *}$ \\
\hline The fifth axis: Educational Outputs & $0.85^{* *}$ \\
\hline
\end{tabular}

Table (8) shows the results of the correlation coefficients indicating a statistical correlation between the axes and the total score of the questionnaire and they ranged from ( 0.60 to 0.85$)$.

\section{- Reliability}

The reliability test was performed by calculating the reliability of the internal consistency using Cronbach's Alpha Reliability coefficient for the questionnaire axes. The results were as follows:

Table 9. Cronbach's Alpha for the reliability of the questionnaire axes and the total score

\begin{tabular}{|l|c|c|}
\hline \multicolumn{1}{|c|}{ Axis } & Item & Cronbach's Alpha Coefficients \\
\hline The first axis: Specialization Identification & 5 & 0.69 \\
\hline The second axis: Teaching Staff & 6 & 0.85 \\
\hline The third axis: Study Plan & 6 & 0.69 \\
\hline The fourth axis: Professional Tests & 6 & 0.68 \\
\hline The fifth axis: Educational Outputs & 10 & 0.86 \\
\hline Total degree of the questionnaire & 33 & 0.83 \\
\hline
\end{tabular}

Table (9) indicates the Cronbach's Alpha Reliability coefficients of the axes indicating that the availability of the reliability degree that ranges between acceptable to high (0.68-0.86), and the general reliability of the questionnaire was $(0.83)$ indicating a high degree of the questionnaire reliability.

\subsection{Statistical Analysis}

Several statistical analyzes were carried out including:

- Frequencies, percentages, arithmetic means and standard deviations of respondents' responses to each paragraph.

- Pearson correlation coefficients to determine the relationships between the study variables.

The arithmetic means have been classified according to the following table: 
Table 10. Classification of arithmetic means categories

\begin{tabular}{|l|l|}
\hline Category & Arithmetic Mean \\
\hline Strongly Agree & $4.24-5.00$ \\
\hline Agree & $3.43-4.23$ \\
\hline Somewhat Agree & $2.62-3.42$ \\
\hline Disagree & $1.81-2.61$ \\
\hline Strongly Disagree & $1.80-1.00$ \\
\hline
\end{tabular}

\subsection{Results}

The calculation of frequencies, percentages, arithmetic means and standard deviations of the questionnaire axes was performed. The results were as follows:

Table 11. Frequencies, percentages, arithmetic means, standard deviations, and the ranks of the items of the specialization identification axis.

\begin{tabular}{|c|c|c|c|c|c|c|c|c|c|c|}
\hline \multirow[t]{2}{*}{ Item } & \multirow{2}{*}{$\begin{array}{c}\text { Frequency/ } \\
\text { Percent }\end{array}$} & \multicolumn{5}{|c|}{ Approval Degree } & \multirow[t]{2}{*}{$\mathrm{AM}$} & \multirow[t]{2}{*}{ SD } & \multirow[t]{2}{*}{ Rank } & \multirow[t]{2}{*}{ Review } \\
\hline & & $\begin{array}{c}\text { Strongly } \\
\text { Agree }\end{array}$ & Agree & $\begin{array}{c}\text { Somewhat } \\
\text { Agree }\end{array}$ & Disagree & $\begin{array}{l}\text { Strongly } \\
\text { Disagree }\end{array}$ & & & & \\
\hline \multicolumn{11}{|c|}{ The first axis: Specialization Identification } \\
\hline \multirow[t]{2}{*}{1} & $\mathrm{~F}$ & 61 & 44 & 13 & 4 & 3 & \multirow[t]{2}{*}{4.25} & \multirow[t]{2}{*}{0.939} & \multirow[t]{2}{*}{1} & Strongly \\
\hline & $\%$ & 48.8 & 35.2 & 10.4 & 3.2 & 2.4 & & & & Agree \\
\hline \multirow[t]{2}{*}{2} & $\mathrm{~F}$ & 2 & 2 & 7 & 36 & 78 & \multirow[t]{2}{*}{1.51} & \multirow[t]{2}{*}{0.809} & \multirow[t]{2}{*}{5} & Strongly \\
\hline & $\%$ & 1.6 & 1.6 & 5.6 & 28.8 & 62.4 & & & & Disagree \\
\hline \multirow[t]{2}{*}{3} & $\mathrm{~F}$ & 4 & 11 & 29 & 37 & 44 & \multirow[t]{2}{*}{2.15} & \multirow[t]{2}{*}{1.100} & \multirow[t]{2}{*}{3} & \multirow[t]{2}{*}{ Disagree } \\
\hline & $\%$ & 3.2 & 8.8 & 23.2 & 29.6 & 35.2 & & & & \\
\hline \multirow[t]{2}{*}{4} & $\mathrm{~F}$ & 12 & 23 & 25 & 27 & 38 & \multirow[t]{2}{*}{2.55} & \multirow[t]{2}{*}{1.347} & \multirow[t]{2}{*}{2} & \multirow[t]{2}{*}{ Disagree } \\
\hline & $\%$ & 9.6 & 18.4 & 20 & 21.6 & 30.4 & & & & \\
\hline \multirow[t]{2}{*}{5} & $\mathrm{~F}$ & 8 & 11 & 20 & 31 & 55 & \multirow[t]{2}{*}{2.09} & \multirow[t]{2}{*}{1.238} & \multirow[t]{2}{*}{4} & \multirow[t]{2}{*}{ Disagree } \\
\hline & $\%$ & 6.4 & 8.8 & 16 & 24.8 & 44 & & & & \\
\hline \multicolumn{7}{|c|}{ General Mean of the axis } & 2.51 & 1.087 & \multicolumn{2}{|c|}{ Disagree } \\
\hline
\end{tabular}

Table (11) refers to the results in the general mean of the specialization identification axis which indicated that the graduates disagree with most of these paragraphs. The most important choices agreed by $(48.8 \%)$ of the sample were the fact that they choose their specialization with a personal desire, while the rest of the paragraphs were reviewed "Disagree" and they were (3) paragraphs and one paragraph was in the category of "Strongly Disagree". 


\section{Macrothink}

Asian Journal of Finance \& Accounting ISSN 1946-052X 2019, Vol. 11, No. 2

Table 12. Frequencies, percentages, arithmetic means, standard deviations, and the ranks of the items of the teaching staff axis.

\begin{tabular}{|c|c|c|c|c|c|c|c|c|c|c|}
\hline \multirow[t]{2}{*}{ Item } & \multirow{2}{*}{$\begin{array}{c}\text { Frequency/ } \\
\text { Percent }\end{array}$} & \multicolumn{5}{|c|}{ Approval Degree } & \multirow[t]{2}{*}{ AM } & \multirow[t]{2}{*}{ SD } & \multirow[t]{2}{*}{ Rank } & \multirow[t]{2}{*}{ Review } \\
\hline & & $\begin{array}{c}\text { Strongly } \\
\text { Agree }\end{array}$ & Agree & $\begin{array}{c}\text { Somewhat } \\
\text { Agree }\end{array}$ & Disagree & $\begin{array}{l}\text { Strongly } \\
\text { Disagree }\end{array}$ & & & & \\
\hline \multicolumn{11}{|c|}{ The second axis: Teaching Staff } \\
\hline \multirow[t]{2}{*}{1} & $\mathrm{~F}$ & 18 & 51 & 34 & 18 & 4 & \multirow[t]{2}{*}{3.49} & \multirow[t]{2}{*}{1.013} & \multirow[t]{2}{*}{2} & \multirow[t]{2}{*}{ Agree } \\
\hline & $\%$ & 14.4 & 40.8 & 27.2 & 14.4 & 3.2 & & & & \\
\hline \multirow[t]{2}{*}{2} & $\mathrm{~F}$ & 21 & 48 & 36 & 14 & 6 & \multirow[t]{2}{*}{3.51} & \multirow[t]{2}{*}{1.052} & \multirow[t]{2}{*}{1} & \multirow[t]{2}{*}{ Agree } \\
\hline & $\%$ & 16.8 & 38.4 & 28.8 & 11.2 & 4.8 & & & & \\
\hline \multirow[t]{2}{*}{3} & $\mathrm{~F}$ & 15 & 44 & 41 & 18 & 7 & \multirow[t]{2}{*}{3.34} & \multirow[t]{2}{*}{1.047} & \multirow[t]{2}{*}{4} & Somewhat \\
\hline & $\%$ & 12 & 35.2 & 32.8 & 14.4 & 5.6 & & & & Agree \\
\hline \multirow[t]{2}{*}{4} & $\mathrm{~F}$ & 12 & 33 & 38 & 33 & 9 & \multirow[t]{2}{*}{3.05} & \multirow[t]{2}{*}{1.099} & \multirow[t]{2}{*}{5} & Somewhat \\
\hline & $\%$ & 9.6 & 26.4 & 30.4 & 26.4 & 7.2 & & & & Agree \\
\hline \multirow[t]{2}{*}{5} & $\mathrm{~F}$ & 7 & 37 & 36 & 30 & 15 & \multirow[t]{2}{*}{2.93} & \multirow[t]{2}{*}{1.116} & \multirow[t]{2}{*}{6} & Somewhat \\
\hline & $\%$ & 5.6 & 29.6 & 28.8 & 24 & 12 & & & & Agree \\
\hline \multirow[t]{2}{*}{6} & $\mathrm{~F}$ & 28 & 36 & 33 & 19 & 9 & \multirow[t]{2}{*}{3.44} & \multirow[t]{2}{*}{1.201} & \multirow[t]{2}{*}{3} & \multirow[t]{2}{*}{ Agree } \\
\hline & $\%$ & 22.4 & 28.8 & 26.4 & 15.2 & 7.2 & & & & \\
\hline \multicolumn{7}{|c|}{ General Mean of the axis } & 3.29 & 1.088 & Some & vhat Agree \\
\hline
\end{tabular}

The general mean of the axis indicated that the graduates somewhat agreed to the reality of the teaching staff in the Saudi universities as shown in table (12). Three paragraphs were in the "agree" category, respectively. The teaching staff at the university is characterized by knowledge and eruditeness with a mean of (3.51), followed by "the teaching staff is characterized by cooperation with students" with a mean of (3.49), then "I can communicate with the faculty member when I need easily" with a mean of (3.44) and the three paragraphs were in the "somewhat agree" category and the item of "The teaching staff is able to benefit from modern technology" was the last one with a mean of (2.93). 


\section{Macrothink}

Asian Journal of Finance \& Accounting ISSN 1946-052X 2019, Vol. 11, No. 2

Table 13. Frequencies, percentages, arithmetic means, standard deviations, and the ranks of the items of the study plan axis.

\begin{tabular}{|c|c|c|c|c|c|c|c|c|c|c|}
\hline \multirow[t]{2}{*}{ Item } & \multirow{2}{*}{$\begin{array}{c}\text { Frequency/ } \\
\text { Percent }\end{array}$} & \multicolumn{5}{|c|}{ Approval Degree } & \multirow[t]{2}{*}{$\mathrm{AM}$} & \multirow[t]{2}{*}{$\mathrm{SD}$} & \multirow[t]{2}{*}{ Rank } & \multirow[t]{2}{*}{ Review } \\
\hline & & $\begin{array}{c}\text { Strongly } \\
\text { Agree }\end{array}$ & Agree & $\begin{array}{c}\text { Somewhat } \\
\text { Agree }\end{array}$ & Disagree & $\begin{array}{l}\text { Strongly } \\
\text { Disagree }\end{array}$ & & & & \\
\hline \multicolumn{11}{|c|}{ The third axis: Study Plan } \\
\hline \multirow[t]{2}{*}{1} & $\mathrm{~F}$ & 42 & 55 & 15 & 12 & 1 & \multirow[t]{2}{*}{4.00} & \multirow[t]{2}{*}{0.959} & \multirow[t]{2}{*}{1} & \multirow[t]{2}{*}{ Agree } \\
\hline & $\%$ & 33.6 & 44 & 12 & 9.6 & 0.8 & & & & \\
\hline \multirow[t]{2}{*}{2} & $\mathrm{~F}$ & 29 & 40 & 27 & 24 & 5 & \multirow[t]{2}{*}{3.51} & \multirow[t]{2}{*}{1.16} & \multirow[t]{2}{*}{4} & \multirow[t]{2}{*}{ Agree } \\
\hline & $\%$ & 23.2 & 32 & 21.6 & 19.2 & 4 & & & & \\
\hline \multirow[t]{2}{*}{3} & $\mathrm{~F}$ & 17 & 50 & 26 & 26 & 6 & \multirow[t]{2}{*}{3.37} & \multirow[t]{2}{*}{1.10} & \multirow[t]{2}{*}{5} & \multirow{2}{*}{$\begin{array}{c}\text { Somewhat } \\
\text { Agree }\end{array}$} \\
\hline & $\%$ & 13.6 & 40 & 20.8 & 20.8 & 4.8 & & & & \\
\hline \multirow[t]{2}{*}{4} & $\mathrm{~F}$ & 27 & 55 & 25 & 13 & 5 & \multirow[t]{2}{*}{3.69} & \multirow[t]{2}{*}{1.05} & \multirow[t]{2}{*}{3} & \multirow[t]{2}{*}{ Agree } \\
\hline & $\%$ & 21.6 & 44 & 20 & 10.4 & 4 & & & & \\
\hline \multirow[t]{2}{*}{5} & $\mathrm{~F}$ & 18 & 29 & 22 & 27 & 29 & \multirow[t]{2}{*}{2.84} & \multirow[t]{2}{*}{1.39} & \multirow[t]{2}{*}{6} & \multirow{2}{*}{$\begin{array}{c}\text { Somewhat } \\
\text { Agree }\end{array}$} \\
\hline & $\%$ & 14.4 & 23.2 & 17.6 & 21.6 & 23.2 & & & & \\
\hline \multirow[t]{2}{*}{6} & $\mathrm{~F}$ & 49 & 23 & 29 & 16 & 8 & \multirow[t]{2}{*}{3.71} & \multirow[t]{2}{*}{1.28} & 2 & Agree \\
\hline & $\%$ & 39.2 & 18.4 & 23.2 & 12.8 & 6.4 & & & & \\
\hline & & Gener & 1 Mean & $f$ the axis & & & 3.52 & 1.16 & & Agree \\
\hline
\end{tabular}

The degree of the general mean of the axis indicated the graduates agree to the quality of the study plan in Saudi Universities as shown in table (13). The graduates agreed that they agreed on four paragraphs, the most important of which was "I have familiar with the study plan and its requirements" with a mean of (4.00), followed by "the hours allocated for practical training are few and insufficient "and that they were somewhat agree to three paragraphs, the least of which was" Practical training during the study enabled me to understand the work environment "with an average of (2.84). 


\section{Ml Macrothink}

Asian Journal of Finance \& Accounting ISSN 1946-052X 2019, Vol. 11, No. 2

Table 14. Frequencies, percentages, arithmetic means, standard deviations, and the ranks of the items of the professional tests axis.

\begin{tabular}{|c|c|c|c|c|c|c|c|c|c|c|}
\hline \multirow[t]{2}{*}{ Item } & \multirow{2}{*}{$\begin{array}{c}\text { Frequency/ } \\
\text { Percent }\end{array}$} & \multicolumn{5}{|c|}{ Approval Degree } & \multirow[t]{2}{*}{$\mathrm{AM}$} & \multirow[t]{2}{*}{$\mathrm{SD}$} & \multirow[t]{2}{*}{ Rank } & \multirow[t]{2}{*}{ Review } \\
\hline & & $\begin{array}{c}\text { Strongly } \\
\text { Agree }\end{array}$ & Agree & $\begin{array}{c}\text { Somewhat } \\
\text { Agree }\end{array}$ & Disagree & $\begin{array}{l}\text { Strongly } \\
\text { Disagree }\end{array}$ & & & & \\
\hline \multicolumn{11}{|c|}{ The fourth axis: Professional Tests } \\
\hline \multirow[t]{2}{*}{1} & $\mathrm{~F}$ & 19 & 45 & 15 & 29 & 17 & \multirow[t]{2}{*}{3.16} & \multirow[t]{2}{*}{1.316} & \multirow[t]{2}{*}{5} & Somewhat \\
\hline & $\%$ & 15.2 & 36 & 12 & 23.2 & 13.6 & & & & Agree \\
\hline \multirow[t]{2}{*}{2} & $\mathrm{~F}$ & 24 & 44 & 25 & 20 & 12 & \multirow[t]{2}{*}{3.38} & \multirow[t]{2}{*}{1.236} & \multirow[t]{2}{*}{4} & Somewhat \\
\hline & $\%$ & 19.2 & 35.2 & 20 & 16 & 9.6 & & & & Agree \\
\hline \multirow[t]{2}{*}{3} & $\mathrm{~F}$ & 18 & 35 & 13 & 35 & 24 & \multirow[t]{2}{*}{2.90} & \multirow[t]{2}{*}{1.382} & \multirow[t]{2}{*}{6} & Somewhat \\
\hline & $\%$ & 14.4 & 28 & 10.4 & 28 & 19.2 & & & & Agree \\
\hline \multirow[t]{2}{*}{4} & $\mathrm{~F}$ & 61 & 34 & 22 & 5 & 3 & \multirow[t]{2}{*}{4.16} & \multirow[t]{2}{*}{1.011} & \multirow[t]{2}{*}{1} & \multirow[t]{2}{*}{ Agree } \\
\hline & $\%$ & 48.8 & 27.2 & 17.6 & 4 & 2.4 & & & & \\
\hline \multirow[t]{2}{*}{5} & $\mathrm{~F}$ & 35 & 35 & 26 & 17 & 12 & \multirow[t]{2}{*}{3.51} & \multirow[t]{2}{*}{1.293} & \multirow[t]{2}{*}{2} & \multirow[t]{2}{*}{ Agree } \\
\hline & $\%$ & 28 & 28 & 20.8 & 13.6 & 9.6 & & & & \\
\hline \multirow[t]{2}{*}{6} & $\mathrm{~F}$ & 29 & 35 & 34 & 18 & 9 & \multirow[t]{2}{*}{3.46} & \multirow[t]{2}{*}{1.202} & \multirow[t]{2}{*}{3} & \multirow[t]{2}{*}{ Agree } \\
\hline & $\%$ & 23.2 & 28 & 27.2 & 14.4 & 7.2 & & & & \\
\hline \multicolumn{7}{|c|}{ General Mean of the axis } & 3.43 & 1.240 & & Agree \\
\hline
\end{tabular}

The degree of the general mean of the axis indicated the graduates approval to professional tests as shown in table (14). Three paragraphs were in the "agree" category, the most important of which was the "The obstacle in the professional tests is the high financial fees" with a mean of (4.16) and three paragraphs were in the "somewhat agree" category, and the lowest was "I registered in some professional tests" with a mean of (2.90). 
Table 15. Frequencies, percentages, arithmetic means, standard deviations, and the ranks of the items of the educational outputs axis.

\begin{tabular}{|c|c|c|c|c|c|c|c|c|c|c|}
\hline \multirow[t]{2}{*}{ Item } & \multirow{2}{*}{$\begin{array}{c}\text { Frequency/ } \\
\text { Percent }\end{array}$} & \multicolumn{5}{|c|}{ Approval Degree } & \multirow[t]{2}{*}{$\mathrm{AM}$} & \multirow[t]{2}{*}{$\mathrm{SD}$} & \multirow[t]{2}{*}{ Rank } & \multirow[t]{2}{*}{ Review } \\
\hline & & $\begin{array}{c}\text { Strongly } \\
\text { Agree }\end{array}$ & Agree & $\begin{array}{c}\text { Somewhat } \\
\text { Agree }\end{array}$ & Disagree & $\begin{array}{l}\text { Strongly } \\
\text { Disagree }\end{array}$ & & & & \\
\hline \multicolumn{11}{|c|}{ The fifth axis: Educational Outputs } \\
\hline \multirow[t]{2}{*}{1} & $\mathrm{~F}$ & 25 & 53 & 28 & 12 & 7 & \multirow[t]{2}{*}{3.62} & \multirow[t]{2}{*}{1.083} & \multirow[t]{2}{*}{4} & \multirow[t]{2}{*}{ Agree } \\
\hline & $\%$ & 20 & 42.4 & 22.4 & 9.6 & 5.6 & & & & \\
\hline \multirow[t]{2}{*}{2} & $\mathrm{~F}$ & 13 & 41 & 37 & 25 & 9 & \multirow[t]{2}{*}{3.19} & \multirow[t]{2}{*}{1.098} & \multirow[t]{2}{*}{9} & \multirow{2}{*}{$\begin{array}{c}\text { Somewhat } \\
\text { Agree }\end{array}$} \\
\hline & $\%$ & 10.4 & 32.8 & 26.6 & 20 & 7.2 & & & & \\
\hline \multirow[t]{2}{*}{3} & $\mathrm{~F}$ & 20 & 64 & 23 & 11 & 7 & \multirow[t]{2}{*}{3.63} & \multirow[t]{2}{*}{1.036} & \multirow[t]{2}{*}{3} & \multirow[t]{2}{*}{ Agree } \\
\hline & $\%$ & 16 & 51.2 & 18.4 & 8.8 & 5.6 & & & & \\
\hline \multirow[t]{2}{*}{4} & $\mathrm{~F}$ & 18 & 53 & 29 & 21 & 4 & \multirow[t]{2}{*}{3.48} & \multirow[t]{2}{*}{1.036} & \multirow[t]{2}{*}{5} & \multirow[t]{2}{*}{ Agree } \\
\hline & $\%$ & 14.4 & 42.4 & 23.2 & 16.8 & 3.2 & & & & \\
\hline \multirow[t]{2}{*}{5} & $\mathrm{~F}$ & 28 & 31 & 25 & 19 & 22 & \multirow[t]{2}{*}{3.19} & \multirow[t]{2}{*}{1.407} & \multirow[t]{2}{*}{10} & Somewhat \\
\hline & $\%$ & 22.4 & 24.8 & 20 & 15.2 & 17.6 & & & & Agree \\
\hline 6 & $\mathrm{~F}$ & 23 & 43 & 23 & 29 & 7 & 3.37 & 1.188 & 7 & Somewhat \\
\hline & $\%$ & 18.4 & 34.4 & 18.4 & 23.2 & 5.6 & & & & Agree \\
\hline 7 & $\mathrm{~F}$ & 22 & 41 & 28 & 24 & 10 & 3.33 & 1.203 & 8 & Somewhat \\
\hline & $\%$ & 17.6 & 32.8 & 22.4 & 19.2 & 8 & & & & Agree \\
\hline 8 & $\mathrm{~F}$ & 29 & 54 & 20 & 13 & 9 & 3.65 & 1.159 & 2 & Agree \\
\hline & $\%$ & 23.2 & 43.2 & 16 & 10.4 & 7.2 & & & & \\
\hline 9 & $\mathrm{~F}$ & 34 & 35 & 22 & 21 & 13 & 3.45 & 1.329 & 6 & Agree \\
\hline & $\%$ & 27.2 & 28 & 17.6 & 16.8 & 10.4 & & & & \\
\hline 10 & $\mathrm{~F}$ & 30 & 37 & 28 & 14 & 6 & 3.65 & 1.109 & 1 & Agree \\
\hline & $\%$ & 24 & 37.6 & 22.4 & 11.2 & 4.8 & & & & \\
\hline & & Gene & al Mean & f the axis & & & 3.46 & 1.165 & & Agree \\
\hline
\end{tabular}

The degree of the general mean of the axis indicated the sample members' approval to the items of the educational outputs as shown in table (15). The course included six paragraphs, their mean was in the "agree" category, the most important of which was "University education contributed to the development of my personal abilities" with a mean of (3.65), and four paragraphs were in the "somewhat agree" category and the lowest was "I am currently working in the field of specialization" with a mean of (3.19).

In order to determine which axes were approved by the sample, the arithmetic means of the axes were ranked and the results were as follows: 


\section{$\triangle$ Macrothink}

Table 16. Rank of the axes according to arithmetic means

\begin{tabular}{|l|c|c|}
\hline \multicolumn{1}{|c|}{ Axis } & Arithmetic Mean & Rank \\
\hline The first axis: Specialization Identification & 2.51 & 5 \\
\hline The second axis: Teaching Staff & 3.29 & 4 \\
\hline The third axis: Study Plan & 3.52 & 1 \\
\hline The fourth axis: Professional Tests & 3.43 & 3 \\
\hline The fifth axis: Educational Outputs & 3.46 & 2 \\
\hline
\end{tabular}

The results in Table (16) indicate that the most agreeable axes was the study plan with a mean of (3.52), followed by the educational outputs with a mean of (3.46), then the professional tests with a mean of (3.43), the teaching staff axis in the fourth rank with a mean of (3.29), and the specialization identification in the last rank with a mean of (2.51).

\subsection{Study Hypnoses Test}

The first hypothesis: There is a relationship between specialization identification and the quality of educational outputs.

Table 17.

\begin{tabular}{|l|c|c|}
\hline \multicolumn{1}{|c|}{ Axis } & Correlation Coefficient & Significant \\
\hline $\begin{array}{l}\text { Relationship between specialization } \\
\text { identification and the quality of educational } \\
\text { outputs }\end{array}$ & -0.04 & Not significant \\
\hline
\end{tabular}

The correlation between the specialization identification and the quality of educational outputs indicated that there was no significant relationship at (0.05) level as shown in Table (17). Thus, according to the results of the study, there was no relationship between the specialization identification and the quality of educational outputs.

The second hypothesis: There is a relationship between the efficiency of teaching staff and the quality of educational outputs.

Table .18.

\begin{tabular}{|l|c|c|}
\hline \multicolumn{1}{|c|}{ Axis } & Correlation Coefficient & Significant \\
\hline $\begin{array}{l}\text { Relationship between the efficiency of } \\
\text { teaching staff and the quality of educational } \\
\text { outputs }\end{array}$ & 0.52 & Significant \\
\hline
\end{tabular}

The results of the relations indicated that there was a significant correlation between the efficiency of the teaching staff and the quality of the educational outputs at a level of (0.01). The correlation coefficient between them was (0.52) as shown in Table (18) and this is logical because the efficiency of the teaching staff has an impact on the educational outputs of the university. Thus, the second hypothesis is that there was a relationship between the efficiency of teaching staff and the quality of educational outputs. 


\section{NI Macrothink}

Asian Journal of Finance \& Accounting

ISSN 1946-052X 2019, Vol. 11, No. 2

The third hypothesis: There is a relationship between the study plan and the quality of educational outputs.

Table 19.

\begin{tabular}{|l|c|c|}
\hline \multicolumn{1}{|c|}{ Axis } & $\begin{array}{c}\text { Correlation } \\
\text { Coefficient }\end{array}$ & Significant \\
\hline $\begin{array}{l}\text { Relationship between the study plan and the quality } \\
\text { of educational outputs. }\end{array}$ & 0.41 & Significant \\
\hline
\end{tabular}

The results indicated that there was a significant correlation between the study plan and the quality of the educational outputs at a significant level of $(0.01)$ with correlation coefficient (0.41) as shown in table (19) and this is logical because the study plan is part of the educational outputs. Thus, the third hypothesis is that there was a relationship between the study plan and the quality of the educational outputs.

The fourth hypothesis: There is a relationship between the professional tests and the quality of educational outputs.

Table 20 .

\begin{tabular}{|l|c|c|}
\hline \multicolumn{1}{|c|}{ Axis } & $\begin{array}{c}\text { Correlation } \\
\text { Coefficient }\end{array}$ & Significant \\
\hline $\begin{array}{l}\text { Relationship between the professional tests and the } \\
\text { quality of educational outputs. }\end{array}$ & 0.39 & Significant \\
\hline
\end{tabular}

As shown in Table (20), there was a significant relationship between the professional tests and the quality of the educational outputs at a significant level of $(0.01)$ and the correlation coefficient was (0.39). This can be explained by the fact that professional tests are an indicator of the quality of outputs. They vary from one student to another and thus the relationship is average because the competency of the graduate does not necessarily have to match the quality of the outputs. Thus, the fourth hypothesis is accepted, namely there was a relationship between the professional tests and the quality of the educational outputs.

\section{Results and Recommendations}

The study concluded the following:

- The approval of the sample was $(48.8 \%)$ on the fact that they chose their specialization with their own desire and without external pressure and this is an excellent indicator. The choice of the student to specialize with his own conviction and desire is often reflected on the level of study and the results achieved.

- The approval of the sample on what is distinguished by the teaching stuff of knowledge and eruditeness, cooperation with students, the possibility of communication between the student and the faculty member when needed easily, while the item of "benefit from modern technology" was the lowest item as the sample was somewhat agree on this item, this may be due to from my personal view (lack of modern technology in some universities, lack of periodic 
maintenance of modern equipment and appliances in universities, difficulty in accessing modern equipment, lack of modern equipment and lack of financial support).

- The approval of the sample on the quality of study plans in Saudi universities and their knowledge of the study plan and its requirements, while the lowest items approved was the item "understanding the working environment during practical application", this may be due to the reservation of some training information and restricting access of students during the application of information and data in order to preserve the clients' privacy. This can be solved by obtaining a pledge from the student to preserve the information and data and not to disclose it or use it, or to view part of the information and data of the company, which does not entail damage to the company.

- The most prominent obstacles of the graduates in the professional tests are the high fees for the professional tests as this was the highest approval items from the point of view of the sample of the study, which led to the lack of registration of some in the professional tests as the item of registration in the professional tests was the lowest approval items in the category " Somewhat agree", and this may be due to the high financial costs of the professional tests as confirmed by the study sample. Therefore, the professional bodies should review the prices of tests, courses, and books issued by them, and the development of prices commensurate with the financial ability of students. In this regard, we find, for example, the Saudi Organization of Certified Public Accountants has provided scholarships and courses for students which is an excellent initiative, and has reduced the prices of training packages, so the professional accounting and financial entities should take into account the financial ability of students.

- The approval of sample members on the quality of educational outputs and the item " University education contributed to the development of my personal abilities" as the highest items approved by the sample, while the item "work in the field of specialization" was the least approved items in the category "somewhat agree".

- There was no relationship between the specialization identification and the quality of educational outputs and this may be due to the possibility of changing the specialization of the student during the university study.

- There was a relationship between (the efficiency of the teaching staff, the study plan, the professional tests) and the quality of the educational outputs.

\section{Recommendations}

- Universities bear a limited part in the responsibility of providing qualified cadres to meet the requirements of the labor market because of the continuous change in the requirements of the labor market. For example, what a brokerage company is looking for from graduates of accounting and financial specializations is different from what is looked for by an industrial company. Thus, the rehabilitation of graduates is an integrative role carried out by several parties, part of which is the educational bodies, the other part is borne by the employer, and part falls on the student so there must be joint cooperation between all parties. 
- Self-development of graduates, the search for integration in the capital market, and the acquisition of experience are required, but the problem lies in the reluctance of some companies to bear the costs of training or rehabilitation of the student, in addition to their fear of leaving the company after being rehabilitated and developed, and this can be solved by obliging the student to serve the company for a similar period for the duration of his training or compensate the company for the costs of training and rehabilitation if he wanted to leave the company.

- Reconsidering the financial costs of the professional tests. The results of the study showed that the sample of the study faced financial difficulties in preparing or conducting professional tests due to the high fees. Therefore, we recommend the review the financial costs of the tests, training packages and fees imposed on the professional tests and make them accessible to new graduates.

- Conducting futures studies about the level of modern technology in universities from the point of view of the members of the teaching staff, the level of accounting education between the public sector and the private sector, and the output of accounting education in the private sector.

\section{Notes}

Note 1. The vision of the Kingdom of Saudi Arabia (2030). Link: https://www.vision2030.gov.sa/sites/default/files/report/Saudi_Vision2030_AR_2017.pdf.

\section{References}

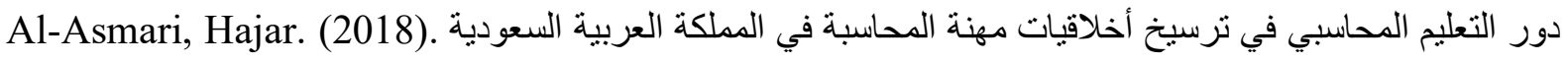

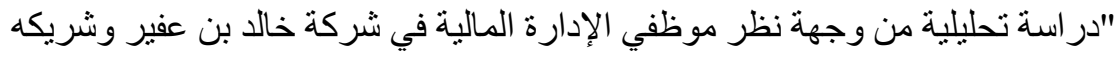

محاسبون ومر اجعون قانو نيون" (The Role of Accounting Education in Establishing Accountancy Ethics in the Kingdom of Saudi Arabia "An Analytical Study from the Point of View of the Financial Management Personnel of Khalid Bin Afair and his Partner Certified, Accountants and Auditors"). Route Educational and Social Science Journal, 5(3), 41-65.

Al-Assaf, Saleh. (2012). المدخل إلى البحث في العلوم السلوكية. Introduction to research in behavioral sciences). Kingdom of Saudi Arabia. Riyadh. Dar Al - Zahraa for Publishing and Distribution.

Al-wabel, Wabel; Juma'ah, Ismael. (1997). (A). برامج التعليم المحاسبي في الجامعات السعودية. (Accounting Education Programs in Saudi Universities). Journal of Accounting. KSA. V. 3. No. 12. pp. 20-25.

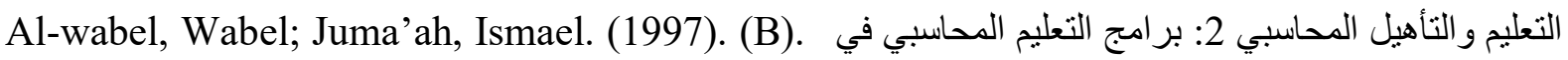
(Education and accounting qualification 2: Accounting Education Programs in Saudi Universities). Journal of Accounting. KSA. V. 4. No. 12. pp. 26-31.

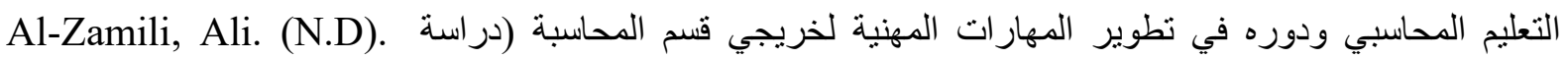
(Accounting education and its role in developing the professional skills of graduates of the accounting department (a survey of the views of a sample of faculty members and graduates of the accounting department at Qadisiyah University)). Journal of Management and Economics, III. The twelfth issue. 
و اقع التعليم المحاسبي في الجامعات الجز ائرية في ظل التوجه . Bouazaria, Hagirah; Londar, Nabelah. 2017

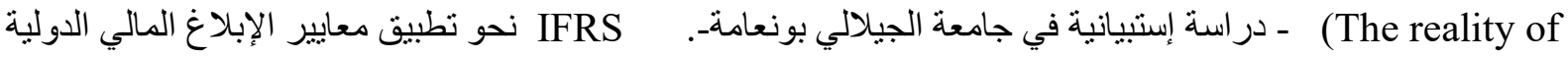
accounting education in Algerian universities in light of going towards the application of International Financial Reporting Standards (IFRS)). Master Thesis. Faculty of Economic and Commercial Sciences and Management Sciences. Université Djilali Bounaama. Algeria.

Boudy, Khalid. (1998). التعليم و التنريب المحاسبي. (Education and accounting training). Journal of Accounting. Saudi. Fifth Edition. No. 19. 34-39.

Hassan, Mahmoud. (2018). مدى تو افق التعليم المحاسبي مع منطلبات سوق العمل "در اسة ميدانبة: على المؤسسات و والجمعيات الأهلية المحلية في قطاع غزة". requirements of the labor market "Field study: on the institutions and local NGOs in the Gaza Strip". Master Thesis. Islamic University of Gaza.

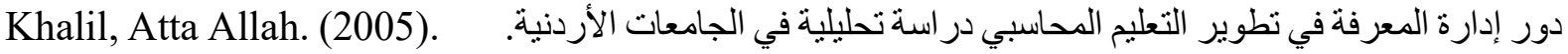
(The Role of Knowledge Management in the Development of Accounting Education: An Analytical Study in Jordanian Universities). Journal of Trade and Finance. Commerce College. Tanta University. Egypt. Issue 2. pp. 221-266.

McGuigan, Nicholas; Kern, Thomas. (2016). CreActive Accounting Education: Visioning Future-Oriented Accounting Programs through a Reflective Unlearning of Current Practice. Journal of University Teaching \& Learning Practice, 13(2).

Murad, Salah. (2011). الأساليب الإحصائية في العلوم النفسية والتربوية و الاجتماعية. (Statistical Methods in Psychological, Educational and Social Sciences). The Anglo - Egyptian Library. Cairo.

Obeidat, Zaokan; Abdul Haq, Kayed; Adas, Abdulrahman. (2007). البحث العلمي مفهومه و أدو اته (Scientific research, its concept, tools and methods. 10th Edition. Dar El Fikr for Publishing \& Distribution.

Qitnani, Khalid; Aweys, Khalid. (N.D). مدى ملائمة مناهج التعليم المحاسبي في الجامعات العمانية لمتطلبات سوق العمل في ظل تداعيات الازمة المالية. The appropriateness of accounting curricula in Omani universities to the requirements of the labor market in light of the repercussions of the financial crisis). Unpublished Research.

Saleh, Abdullah. (2017). أهية تطوير التعليم المحاسبي في ضوء مستجدات معايير الإبلاغ المالي الدولية

ودور ها في تحرير الخدمات المحاسبية في الدول العربية. accounting education in the light of the latest international financial reporting standards and its role in the liberalization of accounting services in the Arab countries. PhD thesis. Faculty of Economic and Commercial Sciences and Management Sciences. Hassiba Benbouali University of Chlef. Algeria.

\section{Appendix (1)}

Dear Mr./Mrs.

(Allah bless him/her)

May the Peace, Mercy and Blessings of Allah be Upon You, 


\section{Macrothink $\Delta$ Institute ${ }^{\text {tm }}$}

This questionnaire aims at identifying the appropriateness of educational outputs in the Saudi universities for the labor market from the point of view of graduates in the financial field, employees in the public sector, private sector, or personal business. The questionnaire consisted of two parts: the first part includes the personal and functional characteristics, the second part includes the study axes, which are 5 axes, 33 paragraphs (the first axis is 5 paragraphs, the second is 6 paragraphs, the third and the fourth are six paragraphs each, and the last is 10 paragraphs). We hope to answer all the items of the questionnaire, and we assure you that all the information required is for the purposes of scientific research only, we appreciate your participation, your views, and your cooperation in this, May Allah grant you and us all the success.

Thank you for your cooperation,

The Researcher

Part 1: Personal and Functional Characteristics:

\begin{tabular}{|c|c|c|c|c|}
\hline 1. Gender & Male ( ) & Female ( ) & & \\
\hline 2. Age & $\begin{array}{l}\text { Less than } 30 \text { years } \\
\qquad\left(\begin{array}{l}\text { ) }\end{array}\right.\end{array}$ & $\begin{array}{l}\text { From } 30 \text { to less } \\
\text { than } 40(\quad)\end{array}$ & $\begin{array}{l}\text { From } 40 \text { to less than } \\
50()\end{array}$ & $\begin{array}{c}50 \text { years and } \\
\text { above } \\
(\quad)\end{array}$ \\
\hline $\begin{array}{l}\text { 3. } \text { Graduation } \\
\text { Date }\end{array}$ & $\begin{array}{c}\text { less than one year } \\
\left(\begin{array}{c}()\end{array}\right)\end{array}$ & $\begin{array}{c}\text { From one year to } \\
\text { less than } 3 \text { years } \\
(\quad)\end{array}$ & $\begin{array}{l}\text { From } 3 \text { years to less } \\
\text { than } 5 \text { years }(\quad)\end{array}$ & $\begin{array}{c}5 \text { years and } \\
\text { above } \\
(\quad)\end{array}$ \\
\hline $\begin{array}{|ll|}\text { 4. University } \\
\text { Name } \\
\end{array}$ & $\begin{array}{l}-1-0-1- \\
-\end{array}$ & & & \\
\hline \begin{tabular}{|ll} 
5. & Scientific \\
Degree
\end{tabular} & Bachelor ( ) & Master ( ) & Ph.D. ( ) & \\
\hline 6. Job & Public Sector ( ) & Private Sector $(\quad)$ & Personal work or & $\operatorname{siness}(\quad)$ \\
\hline
\end{tabular}

Part 2: The study axes

\begin{tabular}{|c|c|c|c|c|c|c|}
\hline Sr. & Items & $\begin{array}{c}\text { Strongly } \\
\text { Agree }\end{array}$ & Agree & $\begin{array}{c}\text { Somewhat } \\
\text { Agree }\end{array}$ & Disagree & $\begin{array}{l}\text { Strongly } \\
\text { Disagree }\end{array}$ \\
\hline \multicolumn{7}{|c|}{$\begin{array}{l}\text { The first axis: Specialization } \\
\text { Identification }\end{array}$} \\
\hline 1 & $\begin{array}{l}\text { I chose this } \\
\text { specialization with my } \\
\text { personal desire }\end{array}$ & & & & & \\
\hline 2 & $\begin{array}{l}\text { I chose this } \\
\text { specialization under } \\
\text { family pressure }\end{array}$ & & & & & \\
\hline 3 & $\begin{array}{l}\text { I chose this } \\
\text { specialization because }\end{array}$ & & & & & \\
\hline
\end{tabular}




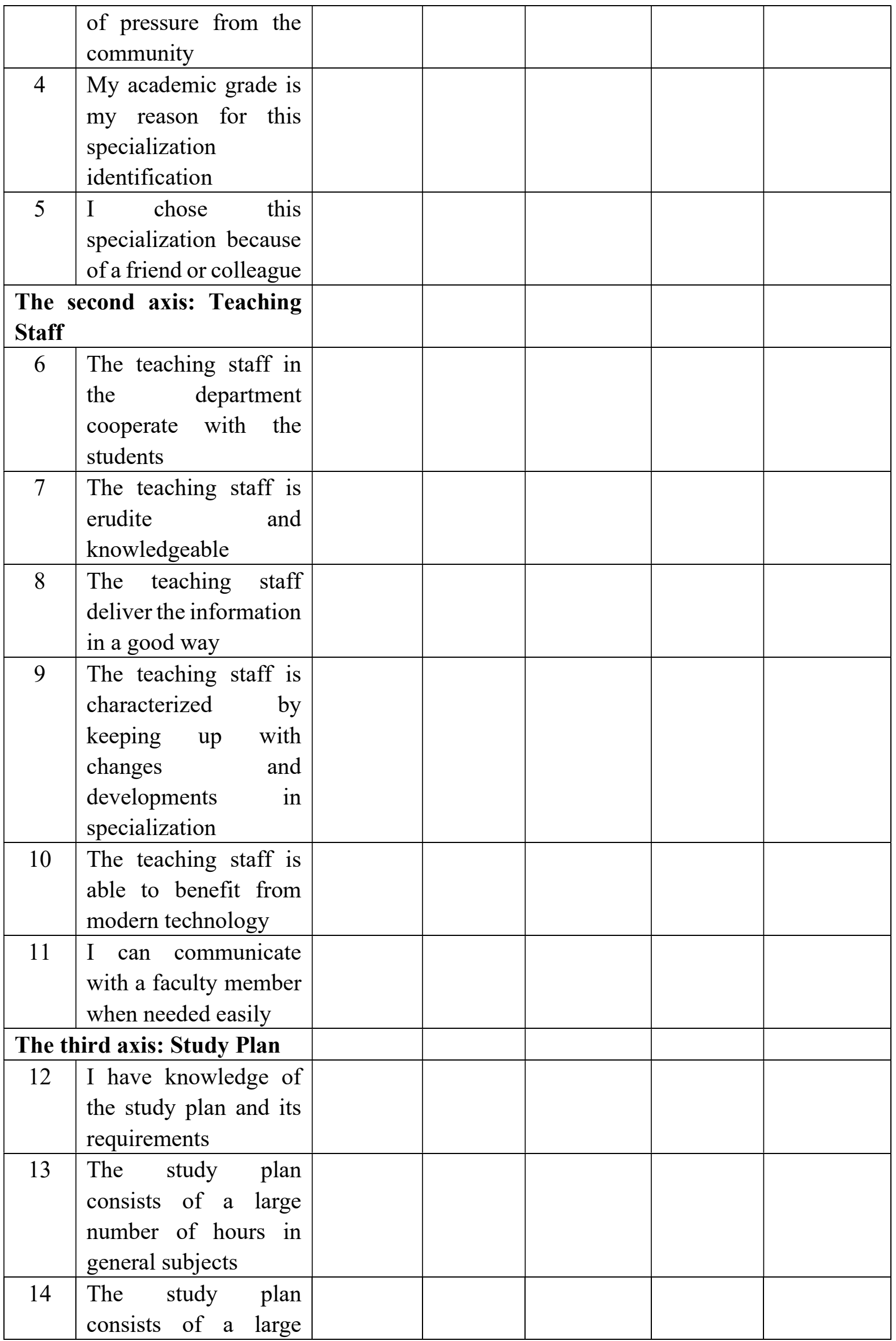




\begin{tabular}{|c|c|c|c|c|c|}
\hline & $\begin{array}{l}\text { number of hours in the } \\
\text { subjects of } \\
\text { specialization }\end{array}$ & & & & \\
\hline 15 & $\begin{array}{lr}\text { The study } & \text { plan } \\
\text { consists of a large } \\
\text { number of hours } \\
\text { required } \\
\begin{array}{l}\text { graduation } \\
\text { for }\end{array}\end{array}$ & & & & \\
\hline 16 & $\begin{array}{l}\text { Practical training } \\
\text { during the study } \\
\text { enabled me to } \\
\text { understand the work } \\
\text { environment }\end{array}$ & & & & \\
\hline 17 & $\begin{array}{l}\text { The number of hours } \\
\text { allocated for practical } \\
\text { training is few and } \\
\text { insufficient }\end{array}$ & & & & \\
\hline \multicolumn{6}{|c|}{$\begin{array}{l}\text { The fourth } \\
\text { Professional Tests }\end{array}$} \\
\hline 18 & $\begin{array}{l}\text { I have knowledge of } \\
\text { the professional tests } \\
\text { and options available } \\
\text { when I graduate }\end{array}$ & & & & \\
\hline 19 & $\begin{array}{l}\text { I have a clear direction } \\
\text { in the area in which I } \\
\text { want to work }\end{array}$ & & & & \\
\hline 20 & $\begin{array}{l}\text { I registered in some } \\
\text { professional tests }\end{array}$ & & & & \\
\hline 21 & $\begin{array}{l}\text { The obstacle in } \\
\text { professional testing is } \\
\text { high financial fees }\end{array}$ & & & & \\
\hline 22 & $\begin{array}{l}\text { The obstacle in } \\
\text { professional tests is } \\
\text { English }\end{array}$ & & & & \\
\hline 23 & $\begin{array}{l}\text { The obstacle in } \\
\text { professional testing is } \\
\text { the availability of } \\
\text { scientific sources }\end{array}$ & & & & \\
\hline \multicolumn{6}{|c|}{$\begin{array}{l}\text { The fifth axis: Educational } \\
\text { Outputs }\end{array}$} \\
\hline 24 & $\begin{array}{l}\text { I benefited from what I } \\
\text { studies in my field }\end{array}$ & & & & \\
\hline
\end{tabular}




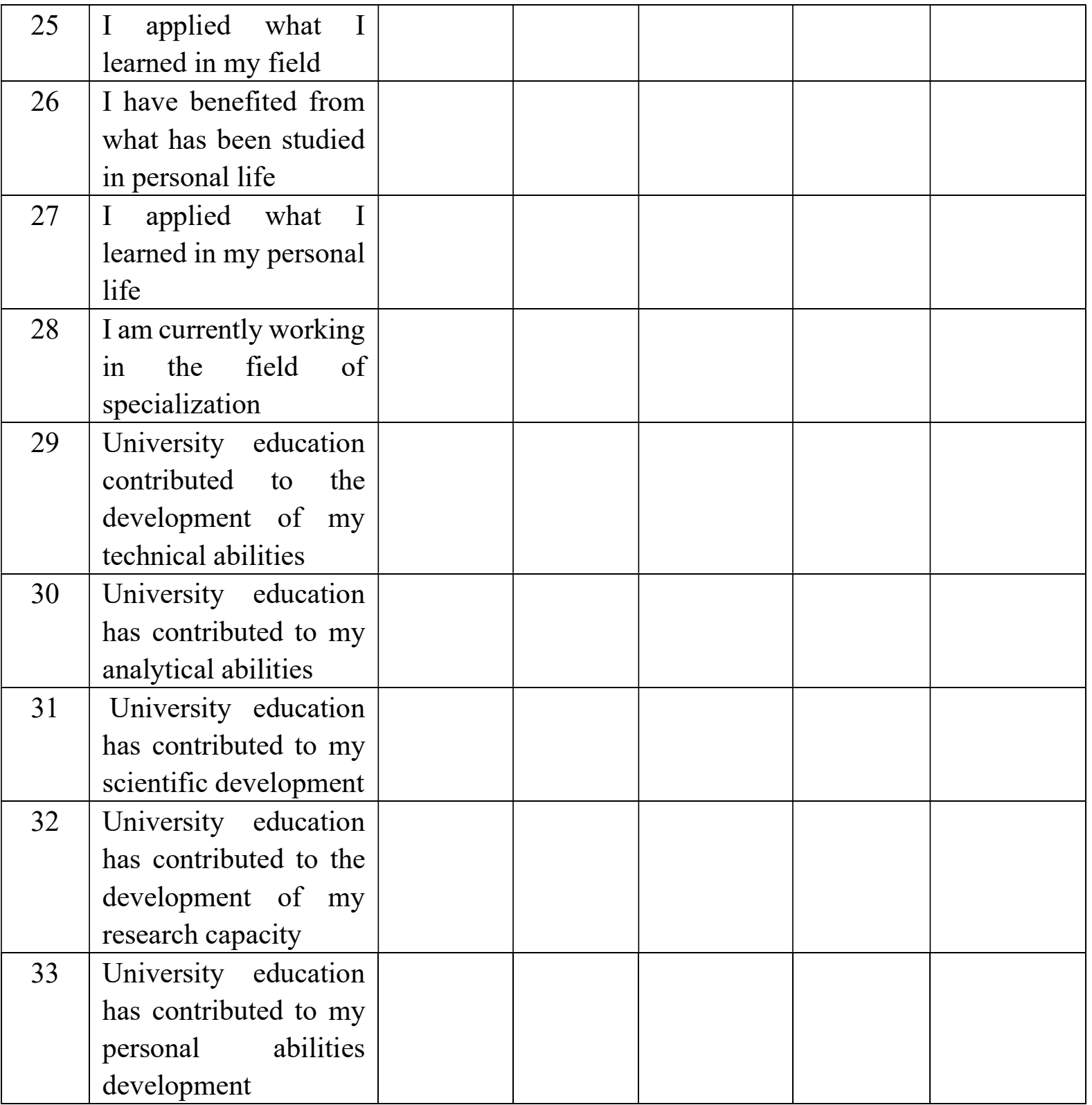

